This item was submitted to Loughborough's Research Repository by the author.

Items in Figshare are protected by copyright, with all rights reserved, unless otherwise indicated.

\title{
'Brain circulation' and transnational knowledge networks: studying long-term effects of academic mobility to Germany, 1954-2000
}

PLEASE CITE THE PUBLISHED VERSION

\section{PUBLISHER}

(c) The Author(s) / @ Blackwell Publishing Ltd \& Global Networks Partnership

\section{VERSION}

AM (Accepted Manuscript)

\section{PUBLISHER STATEMENT}

This work is made available according to the conditions of the Creative Commons Attribution-NonCommercialNoDerivatives 2.5 International (CC BY-NC-ND 2.5) licence. Full details of this licence are available at: https://creativecommons.org/licenses/by-nc-nd/2.5/

\section{LICENCE}

CC BY-NC-ND 2.5

\section{REPOSITORY RECORD}

Jons, Heike. 2019. “'brain Circulation' and Transnational Knowledge Networks: Studying Long-term Effects of Academic Mobility to Germany, 1954-2000". figshare. https://hdl.handle.net/2134/5923. 


\title{
"Brain circulation" and transnational knowledge networks: Studying long- term effects of academic mobility to Germany, 1954-2000
}

Heike Jöns

\section{Please cite the paper as follows:}

Jöns, H (2009) 'Brain Circulation' and transnational knowledge networks:

studying long-term effects of academic mobility to Germany, 1954-2000, Global Networks, 9(3), pp.315-338, ISSN: 1470-2266. DOI: 10.1111/j.1471-

0374.2009.00256.x

\begin{abstract}
"Brain circulation" has become a buzzword for describing the increasingly networked character of highly skilled migration. In this paper, the concept is linked to work on circular mobility of academics in order to explore the long-term effects of their research stays in Germany during the second half of the $20^{\text {th }}$ century. Based on original survey data on more than 1,800 former visiting academics from 93 countries, it is argued that this type of brain circulation launched a cumulative process of subsequent academic mobility and collaboration that contributed significantly to the reintegration of Germany into the international scientific community after World War Two and enabled the country's rise to the most important source for international co-authors of US scientists and engineers in the $21^{\text {st }}$ century. The paper discusses regional and disciplinary specificities in the formation of transnational knowledge networks through circulating academics and suggests that the long-term effects can be fruitfully conceptualized as accumulation processes in "centres of calculation".
\end{abstract}

\section{Keywords}

Academic mobility, centres of calculation, transnational networks, knowledge production, higher education, Germany 


\section{Introduction}

When Zelinsky (1971) formulated "The hypothesis of the mobility transition" more than three decades ago, he stated that there "may be a significant international migration or circulation of skilled and professional persons" in what he called "The advanced society", "but direction and volume of flow depend on specific conditions" (Zelinsky 1971: 230). While Zelinsky's linear understanding of modernization and societal progress has rightly been criticized (e.g., Woods 1993), his prediction of a growing circulation of highly skilled people seems to be quite accurate from the perspective of the early $21^{\text {st }}$ century (Iredale and Appleyard 2001). Whether Castells (2000) explores the "space of flows" or Urry (2000) identifies an emerging culture of mobility at the heart of global society, the circulation of the highly skilled is pivotal to contemporary knowledge economies and has as such only recently received renewed scholarly attention (Beaverstock 2004; Smith and Favell 2006; Jones 2008).

In the literature on migration, the term "brain circulation" was coined to account for increasingly temporary transnational movements of highly skilled professionals (Ackers 2005a). In this paper, this concept is linked to work on circular academic mobility of post-docs and professors ${ }^{1}$ in order to explore the long-term effects of the transnational circulation of academics and its meaning for the constitution of transnational knowledge networks. The paper specifically examines research stays of visiting scientists and scholars in Germany during the second half of the $20^{\text {th }}$ century. Based on survey data on more than 1,800 former visiting academics from 93 countries, it is argued that this type of brain 
circulation launched a cumulative process of subsequent academic mobility and collaboration that contributed significantly to the reintegration of Germany into the international scientific community after World War Two and enabled the country's rise to the most important source for international collaborators of US scientists and engineers in the $21^{\text {st }}$ century. The paper examines regional and disciplinary specificities in the formation of transnational knowledge networks through circulating academics and suggests that the long-term effects for the interacting individuals and their institutions can be fruitfully conceptualized by linking "circular academic mobility" and "brain circulation" to the idea of mobilization processes in "centres of calculation" (Latour 1987).

The paper is structured into three parts. The first part discusses the research context by situating the study within different research agendas and outlining the research methodology. The second part provides an historical geography of academic mobility to Germany in the second half of the $20^{\text {th }}$ century by focussing on the Research Fellowship Programme of the Alexander von Humboldt Foundation as the most significant sponsorship scheme for research stays of visiting academics at German universities and research institutions. The third part examines the nature of continued scientific interaction and subsequent flows of academics after these research stays and explores variations between different decades, regions and disciplines. 


\section{Research context and methodology}

The study of mobility and migration requires an interdisciplinary synthesis "which brings together and integrates a range of perspectives, frameworks, theoretical stances and methodologies" (King 2002: 90). Therefore, this paper is informed by studies that have been conducted in different disciplines but all provide important insights into academic mobility and research stays abroad. As the observation that the "standard academic literature on migration pays virtually no attention to students as migrants" (King and Ruiz-Gelices 2003: 230) applies to academic mobility of post-docs and professors as well, the literature review aims to frame the wider context for this field of research.

\subsection{Academic mobility and "centres of calculation"}

In a narrow understanding, academic mobility refers to professionally motivated circular and other temporary forms of geographical movements by students and academics in higher education and research. These movements include shortterm conference visits as much as long-term stays for the purpose of study, research and teaching, and they often but not always cross national boundaries. The research agenda for this line of inquiry was set by Altbach (1989), who explored "The new internationalism" of foreign students and scholars, and further developed by Blumenthal et al. (1996) in a collection of essays on "Academic mobility in a changing world". In the context of a growing internationalization of higher education and research, studies on academic mobility have multiplied but the main research interest seems to focus on student mobility (Chen and Barnett 2000; King and Ruiz-Gelices 2003; Waters 
2005; 2006; 2007; Findlay et al. 2006) and on career trajectories of academics within Europe (Ackers 2005a; 2005b; Morano-Foadi 2005; Musselin 2004), including long-term geohistorical perspectives (Taylor, Hoyler and Evans 2007).

The reasons for relatively few studies on circular movements of post-docs and professors include a lack of data and its fleeting nature, which both make this type of academic mobility less visible than other transnational movements of the highly skilled. While the UNESCO and a range of national institutions publish data on international student mobility, information on the global circulation of scientists and scholars is only available for a few countries such as Germany, where an annual data report on sponsorship programmes has been published since 2001 (DAAD 2007). Sponsorship programmes have provided the focus of most recent studies on academic mobility of post-docs and professors, either by looking at archival material (Heffernan 1994; Bourquin 2004) or by examining statistical, survey and interview data on the ERASMUS/SOCRATES scheme (Maiworm and Teichler 2002; Enders and Teichler 2005), the Humboldt Award Winner and Research Fellowship Programmes (Jöns 2003a; 2003b; 2007) and EU Marie Curie Fellowships (Van de Sande et al. 2005). Other studies have concentrated on individual universities (Charle 2004; Jöns 2008).

Despite a growing interest in circular movements of academics, the improvement of "the theoretical basis of analysis" (Teichler 1996: 339) remains an important desideratum not only for research on circular academic mobility but also for highly skilled scientific migration more generally (Ackers 2005a: 
101). In this paper, I suggest that a promising conceptual framework for circular movements of scientists and scholars is provided by the idea of cycles of mobilization in "centres of calculation" as discussed in interdisciplinary science studies. Latour (1987: 225) argued that the recurring "mobilisation of anything that can be made to move and shipped back" to scientific centres of calculation - such as the university, the laboratory, the archive and the museum - has shaped the cumulative character of European science from the ages of discovery and exploration and established Europe as the centre of the imperial age. Each full circuit of mobilization added to the accumulation of resources in the centre, thus enabling the production of new knowledge about distant places and phenomena that made these familiar and thereby controllable. Applied to scientific work in the $20^{\text {th }}$ century, the circular process of going away, interacting with other people and research contexts and returning to a home base enables travelling academics to mobilize new and often unexpected resources for knowledge production, to test the value of new arguments in different settings and to spread emerging facts in time and space (Latour 1987: 210-11, 220-22). Academic mobility in the narrow sense precisely resembles this circular form of mobility that Latour considers to be constitutive in the production and dissemination of scientific knowledge (Jöns 2008: 339).

As mobilization processes of scientists and scholars have not only been based on own physical travel but also on correspondence networks and the circulation of others, centres of calculation have benefited from the expertise of visitors and from maintaining contacts at a distance (Fulford et al. 2004). Academic mobility 
to Germany can thus be interpreted as a twofold mobilization process, involving the visiting academics and their institutions as well as the hosting individuals and institutions in Germany. An important aim of the paper is to explore how the research stays have contributed to reinforcing the centrality of different scientific centres of calculation across the world.

The term academic mobility is also used more widely in the literature, accommodating professionally motivated geographical movements of students and academics along a continuum between temporary mobility and permanent migration. Barnett and Phipps (2005) define the related term "academic travel" even more broadly, including not only physical movements but also virtual travel in cyberspace and metaphorical movements across different fields of knowing and understanding. Accordingly, this study is interested in the material, social and intellectual outcomes of circular academic mobility, a phenomenon that could also be captured by the increasingly popular term of "brain circulation".

\section{2 "Brain circulation" and sabbatical leaves}

The concept of "brain circulation" came to prominence in the 1990s as an alternative to notions of "brain drain" and "brain gain" as it accounts for the fact that the emigration of students, academics and other highly skilled professionals increasingly turned out to be temporary rather than permanent (Gaillard and Gaillard 1997; Teferra 2005). The concept thus needs to be understood in the context of "brain drain" studies that built upon initial debates about American recruitment of European talent for their growing economy but have turned their 
focus on highly skilled migration from the global South to the global North and its effects for developing countries (Cervantes and Guellec 2002). While the "brain drain" debate can be linked to a new hierarchy of flows created by Americanization at the height of the USA's hegemonic cycle, "brain circulation" rather accounts for the increasingly networked character of highly skilled migration in the context of recent globalization processes (Taylor 1999: 123-4).

The idea of circulatory movements includes transnational but intra-firm mobility, short-term contracting as well as transient flows of students, academics, managers and IT specialists. By accounting for the complex linkages between expatriates, their home countries and elsewhere (Saxenian 2005), the notion of "brain circulation" helps "to distinguish the issue of knowledge transfer from the physical presence of the individual migrant" (Ackers 2005a: 100). "Brain circulation" thus offers a conceptual alternative to what King (2002: 90) called the "never straightforward boundary between migration and mobility" and thereby converges with the notion of "circular academic mobility". In this paper, both terms are used synonymously for addressing research stays of visiting academics in Germany and similar transient flows.

Research stays abroad are often part of sabbatical arrangements that aim to free academics at regular intervals from their responsibilities in teaching and administration. While sabbatical leaves may serve several purposes, including travel, there is a consensus that they are characterized by an emphasis on research and self-improvement (Sima 2000). Academic mobility to Germany in 
the context of the Humboldt Research Fellowship Programme was largely governed by such general motivations for a sabbatical, including the search for new academic experiences and time to do research and publish. The most important motivations related to Germany more specifically were the prestige of the Humboldt Foundation, a particular research project, the scientific reputation of the host institution and a cultural/historical interest in the country (Jöns 2007).

On the site of the benefits, the sabbatical leave has been regarded "as an investment in the future of the institution granting [the leave]" (Sima 2000: 73). This nicely ties in with the idea of mobilization processes in centres of calculation: Academics go out into the world to gather new experiences and resources for research and teaching at their home institution. By examining the extent to which research stays abroad resulted in international collaborations and other knowledge networks, the paper tackles a second main research desideratum on highly skilled scientific migration, namely long-term effects of brain circulation (Robertson 2006; Regets 2007).

\subsection{Transnational knowledge networks}

According to Altbach (1989: 125), "[a]cademic institutions ... are connected by an international knowledge network that communicates research worldwide through books, journals and, increasingly, data bases. ... More than any other major institution, the university is by its nature international." Such general appeals to the international nature of universities are contradicted, inter alia, by recent studies that point to the strong national orientation of academic labour 
markets and careers in contemporary Europe (Musselin 2004). In this paper, it is argued that academic institutions are not international by their nature but that they may become international by establishing external relations. As the concept of centres of calculation indicates, circular academic mobility plays an important part in this process, and thus also for the formation of long-term international networks between different sites of knowledge production.

Parmar (2002) defines an international knowledge network as "a system of coordinated research, disseminated and published results, study and often graduate-level teaching, intellectual exchange, and financing, across national boundaries". His particular interest are the ways in which the Rockefeller, Carnegie and Ford Foundations created such international knowledge networks after 1945 by fostering "a pro-US environment of values, methods and research institutions across a range of fields and academic disciplines" (Parmar 2002: 13). He points out that the work of the foundations was far from being "value free", "neutral" or "non-political" as most existing scholarship would argue when claiming that "foundations merely sponsor good ideas or knowledge for its own sake, rather than for political, strategic, or ideological ends" (Parmar 2002: 15).

The work of the Humboldt Foundation as a mediator organization of foreign cultural policy has certainly to be evaluated in a similar context, even if the Research Fellowship Programme distinguishes itself from more targeted schemes by the openness for applications from all countries and disciplines and the lack of regional or disciplinary quotas for the selection of research fellows. 
However, the foundation has still acted as one of those "intellectual actors with large financial resources, strategic vision, and ... official policy guidance [that have] the power to define academic fields, to identify the most talented individuals, and the resources to build up key institutions, and thereby consolidate [state] power, especially during the Cold War" (Parmar 2002: 14-5). While this paper does not explore the selection committees' strategies and policy guidance, it discusses some of the political, economic, cultural and intellectual contexts in which the formation of transnational knowledge networks through state-sponsored academic mobility has been situated.

\subsection{Methodological considerations}

By analyzing long-term effects of academic mobility to Germany from 1954 to 2000 , this paper aims to reveal some of the ways in which visiting academics contributed to the formation of transnational knowledge networks. The study is based on data collected by the Alexander von Humboldt Foundation (Bonn, Germany) on their Research Fellowship Programme and on an own postal survey among former Humboldt research fellows. The questionnaire survey, conducted in 2003 , was sent to a systematic sample of 3,718 former research fellows from five decades, equalling every fourth of those still in contact with the foundation ( $n=15,261,89$ percent) and every fifth of all research fellows in the period 1954 to $2001(\mathrm{~N}=17,216)$. After sending one reminder, the response rate amounted to 51 percent, or 1,893 questionnaires, of which 1,809 enter this analysis (1954-2000). The study thus analyzes the responses of roughly every

ninth Humboldt research fellow who came to Germany in the period 1954 to 
2000 (10.8 percent). The high response rate can be attributed to individual sponsorship, a range of follow-up contacts and the fellows' gratitude to the Humboldt Foundation. Due to the increasing age of former research fellows, the first two decades are slightly underrepresented (1950s: 6.8 percent; 1960s: 8.6 percent), while the last two decades are slightly overrepresented (1970s: 10.3 percent; 1980s: 11.0 percent; 1990s: 12.9 percent).

The analysis subscribes to a relational approach that acknowledges the ways in which "knowledge formation and power over knowledge in the global economy is moving out of the control of the nation state" (Carnoy and Castells 2001: 11; my italics). There are, however, two reasons why the analysis compares interactions and flows on the level of countries and larger geographical regions: first, the Humboldt Foundation is a national agency that sponsors research stays within Germany, even if eligible host institutions include a few research institutions in neighbouring countries (e.g., the CERN in Geneva); second, and more importantly, the flows of academics studied in this paper are so complex in themselves that geographical and cultural variations are compared on the national/supranational level in order to reduce complexity. This methodological compromise is not seen to contradict the "space of flows" that undermines national boundaries in contemporary globalization. The national/supranational level is rather constituted as aggregations of "centres of calculation" in order to map global flows of academics over five decades. 
By applying a long-term perspective to academic mobility of post-docs and professors, the study aims to test the hypothesis that this type of brain circulation launched a cumulative process of subsequent mobility and collaboration that contributed significantly to the reintegration of the Federal Republic of Germany into the international scientific community in the 1950 s and 1960s and enabled the country's rise to the most important source for international collaborators of US scientists and engineers. Seeking to present a comprehensive picture of these long-term effects, the following sections pay particular attention to variations between countries, disciplines and decades.

\section{Visiting researchers in Germany}

After the Second World War, higher education and research in West Germany was preoccupied with rebuilding the universities and reviving international academic relations (Heinemann 1994). First impulses for the reintegration into the international scientific community came from exchange programmes of the allied powers (Kellermann 1978) and from lecture tours or guest professorships of visiting academic emigrants (Krauss 2006). These were followed by the (re)establishment of institutions supporting academic work within and beyond the country such as the Max Planck Society (1948), the German Academic Exchange Service (1950), the German Research Council (1951), the Goethe Institute (1952) and the Alexander von Humboldt Foundation (1953). As many of these institutions, the Humboldt Foundation was modelled on predecessor organizations: The first institution, founded two years after the death of the renowned explorer Alexander von Humboldt (1769-1859) in Berlin, had 
supported scientific research and travel of German scientists, while the second institution, re-established in Berlin in 1925 after the institution's bankruptcy during the economic crisis of 1923, facilitated postgraduate studies of foreign graduates in Germany until 1945 (Jansen 2004). The third institution, established by the Federal Republic of Germany in Bonn in December 1953, adopted the idea of sponsoring visiting academics in Germany by establishing the Humboldt Research Fellowship Programme. In the period 1954 to 2000, this programme supported 16,699 visiting academics from 131 countries (Figure 1). As the most significant funding scheme for research stays of visiting post-docs and professors at German universities and research institutions (DAAD 2007), it reveals important developments in the history and geography of transnational academic mobility to Germany (Jöns 2003b).

[Please insert Figure 1 here]

The increasing numbers of applications and research fellowships from the 1950s to the 1980s reflect the reintegration of Germany into the international scientific community after the Second World War, the expansion of German higher education and research in the 1960s and 1970s, and a considerable improvement of research infrastructure and quality in the 1980s (Figure 2). These processes went hand in hand with rising scholarship funds and an increase in the academic qualification, age and career stage of applicants and research fellows, thus leading to several revisions of the programme's statutes (Jansen 2004). The benchmark for granted fellowships was gradually lifted from 
300 (1962) via 440 (1973) to 500 per year (1980), while the age limit for applicants was raised from 30 via 38 (1962) to the flexibly handled threshold of 40 years (1973), resulting in an average age of 35 years (1954-2000). After a number of doctoral students had been funded in the early years of the programme, a doctorate became obligatory for successful applicants from most countries in the early 1970s. In line with these developments, the foundation's objective to support study leaves had been changed to research stays in 1965 . Therefore, this study has to consider a slight change in the profile of visiting researchers from a high share of postgraduates in the 1950s to almost only post-docs and professors from the 1970s onwards.

[Please insert Figure 2 here]

In the 1950s, not long after the end of the brutal Nazi regime, the visiting academics' experience of everyday life in post-war Germany was of particular importance for rebuilding trust in German research and society. Short visits, guest professorships and research stays of academics from abroad also paved the way for the import of new ideas and methods necessary for updating higher education and research to the latest state of international scholarship (Krauss 2006). During this time of restructuring, the opportunity for studies in Germany was mostly attractive for junior academics from developing and industrializing countries. Accordingly, most visiting researchers came from Japan (15 percent), India (9 percent), Greece (7 percent), Spain (6 percent), Argentina, Turkey and Italy (5 percent each). 
The policy of allying the Federal Republic with the Western powers led to particularly strong academic ties with western countries. From the 1950s to the 1970s, the share of visiting researchers from the USA continuously increased, while exchanges with the Soviet Union and China started only in the 1970s (Figure 3a). During the reform period of the Prague spring of 1968, the small country of Czechoslovakia became the country with most applications, while the start of diplomatic relations with Poland in 1972 generated a boom in applications that brought many Polish academics to Germany in the 1980s. The fall of the Iron Curtain led to a sudden increase in applications from the Soviet Union's successor states and the transformation states of Central and South Eastern Europe, while the historically unique situation of reunification generated a higher interest in Germany in other countries as well (Figure 2).

Based on enormous state investment in research and development, increasing funds for the mediator organizations of foreign cultural policy, and information dissemination about the sponsorship programme, Germany attracted more and more visiting scholars from leading scientific nations in the 1970s and 1980s. In the 1980s, most academics came from the USA (13 percent), Poland (11 percent) and Japan (10 percent), while the 1990s saw an increase in applications and fellowships from China (12 percent) and Russia (11 percent), the USA (10 percent) being the third and Japan and India the fourth and fifth most frequent country of origin (7 percent each). This shift of regional emphasis was mainly related to the end of the Cold War and to the growth of Chinese science, while a worldwide decentralization of international scientific contacts 
and growing opportunities for transnational academic mobility enhanced international competition for visiting researchers in the 1990s, thereby consolidating the number of applications and granted Humboldt research fellowships on the level of the 1980s.

Important changes also occurred in regard to the disciplinary profile of the visiting researchers as this shifted from an emphasis on the humanities to a dominance of the natural and engineering sciences (Figure 3b). Responsible for this shift was not only the targeted development of research facilities in the natural and technical sciences since the 1960s (Weingart 1998) but also the fact that investment in research infrastructure can easily attract new visiting researchers in the English-speaking laboratory and "big" sciences. The mobilization of visiting scholars in the arts and humanities appears to be much more difficult as language plays a central role for research projects in these fields, and the potential of foreign academics with German language skills is not only limited but also declining for historical reasons (Jöns 2007).

[Please insert Figure 3 here]

On average, every third application for a Humboldt research fellowship got approved over the years, but the success rates varied enormously between countries of origin. Among the 25 most frequent source countries, the success rates ranged from about 20 percent for applications from Egypt, India and Pakistan to c. 50 percent for applications from Japan, Australia, the USA, 
Canada, the UK and France, thus reflecting and reproducing the asymmetrical power-geometries of global higher education and research. The average length of the main research stay was eleven months, while c. 60 percent of the visiting researchers extended their main stay by an average of seven months. The following analysis thus looks at long-term research stays of more than a year, the great majority of which were based at universities (80 percent).

\section{The formation of transnational knowledge networks}

Transnational knowledge networks in higher education and research are well researched in regard to international co-authorship in the natural and technical sciences as these are recorded in science citation databases (Luukkonen et al. 1992; Wagner and Leydesdorff 2005a). Comparing the patterns of international co-authorship in scientific and technical research for the periods 1981-85, 199195 and 2001-05 reveals a striking development (Table 1). In the period 1981-85, Germany was the third most important source country for international coauthors of US scientists and engineers, ranging behind the English-speaking countries UK and Canada, and before France and Japan. Ten years later, Germany had closed the gap to the UK and Canada with all three countries providing 10 percent of the international co-authors for US journal articles. Remarkably, this trend continued so that at the beginning of the $21^{\text {st }}$ century Germany provided the highest share of international co-authors for articles written in the global centres of knowledge production. The number of coauthored scientific and technical articles by researchers working in the USA and Germany had increased more than sevenfold since $1981-85$, from c. 5,800 via 
c. $11,500(1991-95)$ to 43,921 articles in $2001-05$ (+657 percent), which even exceeded the trend of massive internationalization in scientific publishing worldwide (+564 percent; calculations based on National Science Board 1998; 2008; Adams, Gurney, Marshall 2007).

[Please insert Table 1 here]

In this final part of the paper, I argue that the enormous increase in international collaboration between Germany and the USA is the result of a cumulative process of academic mobility and collaboration launched and maintained by the brain circulation in the Humboldt Research Fellowship Programme and similar schemes for circular academic mobility. In support of this argument, I present empirical evidence on the type of continued interaction, subsequent mobility patterns and the visitors' most important international collaborations.

\subsection{Continued scientific interaction?}

One way to measure the impact of academic mobility on research collaboration is to compare the situation before and after the research stay abroad. Before the first Humboldt stay, every fifth research fellow had written joint publications with colleagues in Germany; as a result of the research stay, two thirds of the visiting researchers published joint academic work with their German colleagues. While this share had risen from 52 percent in the 1950 s to 71

percent in the 1990s, the largest change took place from the 1960 s to the 1970s, thereby reflecting the growing importance of the natural and technical 
sciences and their trend towards multi-authorship (Wagner and Leydesdorff 2005b). Despite considerable variation in the amount of resulting joint publications between types of research work dominated by collective and by individual scholarship (Jöns 2007), these figures indicate that the visiting researchers' physical presence in Germany led to a number of research collaborations that would not have happened otherwise.

After the research stay, the established linkages between the guests and their German colleagues proved to be quite sustainable as more than every second visiting academic engaged in occasional or even regular collaboration after the research stay (54 percent). Most of the other researchers maintained contacts through occasional or regular information exchange; only 5 percent had no further scientific contacts with colleagues in Germany (Table 2). These figures are related to the situation that 92 percent of the visiting academics worked permanently in research throughout their career. The important role of academic mobility for maintaining and deepening existing scientific contacts is illustrated by the fact that those two thirds of the visiting researchers who had previous academic contacts in Germany were more frequently involved in occasional/regular collaboration after the research stay than those who did not have these previous contacts (60 compared to 45 percent). However, the still very high share of those who continued collaboration after the research stay without having had previous academic contacts highlights the significant part academic mobility plays for the creation of new transnational knowledge networks, thus empirically supporting Regets' (2007: 14) presumption that 
"international migration [of scientists and engineers] leads to increased international collaboration and transmission of knowledge".

The frequency of continued collaboration with colleagues in Germany after their research stay did not vary significantly between disciplines, but the nature of these collaborations differed substantially. While it can be expected that regular collaboration in the natural and technical sciences almost certainly implied the publication of joint and often multi-authored papers in internationally peerreviewed journals, continued interaction in the arts and humanities, and to a lesser extent also in the social sciences, often involved activities beyond the coauthorship of journal articles. Table 2 elucidates some of these less well documented dimensions of transnational knowledge networks, which include contributions to German-language scientific journals and book series as well as refereeing for German students/researchers and the funding agencies themselves, particularly in the arts and humanities. Scientific consulting and related services for the private and public sectors were most common in engineering and medicine as academic fields with a strong applied component. While roughly every tenth Humboldt research fellow accepted a permanent job in Germany, the following section explores temporary subsequent movements as the most significant long-term effects of academic mobility to Germany.

[Please insert Table 2 here] 


\subsection{Subsequent academic mobility}

Transnational flows of students and academics resulting from research stays abroad reveal the spatialities of transnational networks characterized by Featherstone et al. (2007: 383-4) as "the diverse ongoing connections and networks that bind different parts of the world together". The visiting researchers established such transnational connections by mostly going back to their country of origin and thus performing circular academic mobility in the truest sense (at least two thirds). About 12 percent stayed in Germany for at least another temporary post, while c. 9 percent used their research stay abroad as a springboard for a job/career in a third country.

Ackers (2005a: 122) reminds us that "Many scientists retain links with host institutions when they return home or move elsewhere, building a web of relationships across time and space which shape not only their own careers but those of their students and colleagues". Precisely this process happened in the case of academic mobility to Germany as almost 90 percent of the research stays generated subsequent mobility of students and academics: from abroad to Germany (86 percent), from Germany to abroad (58 percent), and in both directions (56 percent). Two thirds of the Humboldt research stays generated further long-term stays of over one month in Germany, while one fifth of these stays led to long-term stays abroad (the other movements were comprised of short-term visits of up to one month only). 
This pattern was surprisingly stable from the 1950 s to the 1980 s and varied only slightly in the 1990s because less time had passed to generate subsequent academic mobility. However, as the number of Humboldt research fellows had increased more than five-fold from the 1950s to the 1980s, ever more students and academics came to Germany and went abroad. This fuelled the cumulative process of academic mobility and collaboration that speeded up Germany's reintegration into the international scientific community, fostered the internationalization of higher education and research and enabled the strong collaborative links between Germany and the USA. Expressed in numbers, 837 research stays in the 1950s generated at least 635 further long-term stays in Germany and at least 245 long-term stays abroad, while 4,455 research stays in the 1980 s generated more than 3,000 further long-term stays in Germany and more than 1,000 long-term stays abroad. As the research fellows often influenced subsequent mobility of different groups of people and as there is no information available about how many undergraduates, doctoral students, postdocs and professors actually circulated per person, the true figures of subsequent long-term stays may be much higher. However, the important point is that the intensifying brain circulation was related to the exchange of knowledge and ideas and often involved the material transfer of research objects and infrastructure as well, thus reinforcing the centrality and international connectivity of German academics, research groups and institutions through accumulation processes practiced by a growing number of incoming and outgoing students and academics. 
The multiplication effect of the visiting researchers is also documented in a steadily growing share of Humboldt research fellows that had received information about the Fellowship Programme from former research fellows (1950s: 14 percent; 1990s: 44 percent). Similarly, the multiplication effect of students and researchers from Germany had grown considerably from the 1950s (12 percent) to the 1990s (31 percent), thus fitting the picture of intensified brain circulation from and to Germany. As a response to the growing demand and differentiation of circular academic mobility, the Humboldt Foundation introduced two new scholarship programmes in the 1970s. The Humboldt Award Winner Programme has sponsored long-term research stays of US senior scientists in Germany from 1972 onwards (Jöns 2003a), while the Feodor Lynen Research Fellowship Programme has supported long-term research stays of German post-docs at the host institutions of former Humboldt visiting scientists and scholars since 1979 (Humboldt Stiftung 1999).

\subsubsection{The composition of flows}

Comparing the subsequent flows of students and academics by career stage reveals that the visiting researchers provided the most important link in the subsequent circulation (Figure 4). Frequent short-term visits of German hosts and other German professors abroad reflect a distinct division of labor within large research groups in the natural and technical sciences, where established professors often are in a managerial position, concentrating mainly on grant acquisition, strategic planning, teaching and supervision, administration and service to the discipline, while doctoral students and post-docs do research at 
the bench (Latour 1987: 156). At an advanced stage of their career, many professors therefore conduct a number of short visits abroad to keep up-to-date and to maintain their transnational networks rather than doing research in one place for an extended period. Previous studies suggest that this situation is particularly developed in Germany, which goes hand-in-hand with a less developed sabbatical culture, at least in the natural and technical sciences (Jöns 2003a: 377-96; 407-18). Also, most subsequent long-term stays were facilitated by existing sponsorship programmes, while there seems to be no prestigious scheme for long-term research stays of German professors abroad, which raises wider questions about the relationship between academic routines, sponsorship programmes and transnational flows of academics.

[Please insert Figure 4 here]

The subsequent movements of academics varied between disciplines and countries of origin, while still reflecting the overall pattern of academic mobility at different career stages (Table 3a). In the arts and humanities, for example, return stays of the Humboldt research fellows and subsequent stays of other foreign professors were particular frequent as the personal access to books, archival resources and other relevant research objects can be regarded as pivotal for research practices characterized by a high degree of individual scholarship. In mathematics, a field in which individual work is very common as well, the pattern of subsequent academic mobility was very close to that in the arts and humanities, while the figures confirm that the "expectation of mobility" 
is particularly high for post-docs in the natural and technical sciences, particularly in physics (Ackers 2005a: 104).

[Please insert Table 3 here]

A growing visibility of subsequent post-doc mobility from the USA to Germany between the 1970s (4 percent) and the 1990s (12 percent) reflects the rising international reputation of research in Germany during this period, even if the subsequent inflow of post-docs from all other regions remained more frequent. Much more significant for the establishment of academic linkages between the two countries were subsequent flows of German post-docs to the global scientific centres in the USA. The comparison of geographical regions shows that North America not only attracted many more post-docs from Germany than any other region but in fact represents the only region in which more post-docs were received from Germany than sent to. This situation illustrates three important characteristics of contemporary global higher education and research: first, the active mobilization of foreign post-docs by US laboratories and research groups; second, the great significance of international and in particular US research experience for an academic career in Germany and other European countries; and third, the strong linkages that brain circulation has established between research groups in Germany and the USA, thus facilitating a higher share of international co-authorship with US scientists and engineers than between the USA and the English-speaking countries UK and Canada. 
The subsequent flows also show that Germany was particularly attractive for students and academics from Central and South America, East Central Europe, the successor states of the Soviet Union, Africa and South Asia (Table 3b). Shaped by unequal socio-economic conditions, varying scientific standards, different academic cultures and the power-geometries of global higher education and research, these movements to Germany as one of the leading scientific nations worldwide can be interpreted as circuits of mobilization from emerging and less well-equipped scientific centres of calculation across the world. The travelling students and academics frequently transferred new research experiences as well as textual, methodological, technological and other resources back home, often capitalizing on the acquired knowledge and resources "in terms of deriving status, authority and academic qualifications from [them]" (Crang 2003: 139). Many research fellows who returned to the less prosperous sites of scientific inquiry in South East and East Central Europe, South East and South West Asia and Central and South America used the possibility to receive donations for books and equipment from the Humboldt Foundation, thus reminding us of the profound material dimension of brain circulation and networked transnational practices more generally (Featherstone et al. 2007). The immense flow of visiting researchers from China to Germany in the 1990s is another very visible component of cycles of accumulation that contribute to what de Certeau (1986: 146) called the "stockpiling" of knowledge through a repetitive going out into the world and returning to a home base, thus fostering the emergence of new global centres of knowledge production in the $21^{\text {st }}$ century (Leydesdorff and Zhou 2005). 


\subsubsection{The impact of flows}

The extent to which academic mobility to Germany established transnational knowledge networks across the world is also evident in a comparison of the geographies of international co-authorship in scientific and technical research (1991 to 1995) with the geographies resulting from the five most important international scientific collaborations of Humboldt research fellows from the natural and engineering sciences (1981 to 2000). Table 4 compares the relevant figures for the 12 most important countries of origin and reveals that most visiting researchers conducted their most significant international collaborations with colleagues in Germany. The physical co-presence for an extended period of time thus created many more collaborative links than the shares on international co-authorship would suggest. Strikingly, the visiting researchers' particular emphasis on collaborative links with Germany represents the only major difference to the geographies of co-authorship as in all but one case the second and third ranked countries resemble the sequence of nations in the ranking on co-authorship.

[Please insert Table 4 here]

In the age of email, conference travel and the internet, long-term research stays abroad may only provide one of many opportunities for getting involved in international scientific collaboration, but the presented empirical data clearly illustrate that this type of circular academic mobility has played a significant part in the formation and maintenance of transnational knowledge networks. These 
networks are themselves maintained by various forms of brain circulation and have linked German higher education and research, as indicated in Table 4, relatively closely to very different research contexts around the world.

\section{Conclusions}

Zelinsky's (1971) anticipation of a growing international circulation of highly skilled professionals is partly confirmed by the increase of circular academic mobility to Germany from the 1950 s to the early 1990s. The direction and volumes of these flows were indeed shaped by a number of contextual factors such as the improvement of socio-economic conditions in the Federal Republic, the Cold War, the expansion of higher education and research and a considerable rise in the quality of German research infrastructure and performance since the 1970s. Since the end of the Cold War, however, new opportunities for academic mobility worldwide led to a decentralization of international scientific contacts, thus stopping the impressive increase of brain circulation in the Humboldt Research Fellowship Programme and triggering a period of intensified international competition for academics that has recently been tagged as "Talent Wars" (Universities UK 2007; Hoyler and Jöns 2008).

This paper examined some of the long-term effects of circular academic mobility to Germany in the period 1954 to 2000 by providing a first quantification of continued interaction and subsequent flows of students, post-docs and professors. The empirical evidence on the Humboldt Research Fellowship Programme supports Welch's (1997: 340) argument that "[s]chemes such as 
DAAD, ERASMUS, NAFTA, Fulbright and UMAP are important mechanisms to sustain internationalization". By launching a cumulative process of transnational academic mobility and collaboration, the state-sponsored research stays in Germany accelerated the countries' reintegration into the international scientific community after World War Two, enabled close linkages to a number of different research contexts across the world, and made Germany the most important source for international co-authors of US scientists and engineers in the early $21^{\text {st }}$ century.

The study has shown that the formation of transnational knowledge networks through brain circulation includes many dimensions beyond the well documented international co-authorship of journal articles in the natural and technical sciences. Most importantly, this process involves subsequent flows of students and academics that exemplify what Faulconbridge (2007: 925) characterized as "globally stretched practices of knowledge production and circulation" in the realm of global higher education and research. While academic mobility seems to be as often the consequence of transnational knowledge networks as it creates new academic linkages, the paper suggests that its conceptualization as part of mobilization processes in scientific centres of calculation provides a promising way for studying "the relationship between the sabbatical leave and the benefits that accrue to the community and society" (Sima 2000: 74). On the one hand, state-sponsored academic mobility to Germany helped to mobilize international expertise, contacts and material resources that reinforced the centrality of the emerging and later established 
centres of knowledge production within the country. On the other hand, these circulatory movements were part of accumulation processes at the visiting researchers' home institutions, with subsequent interactions often involving a number of people and projects.

The study also revealed a wide range of research desiderata on academic mobility of post-docs and professors and resulting knowledge networks. This includes a critical engagement with the politics of state-sponsored academic mobility, the quantification of flows and effects beyond the nation state as well as in-depth studies on the actual impact on knowledge production and related material, social and intellectual exchanges. In this context of an emerging research field, the paper aimed to draw the attention to the significant role of circulating academics for the construction of global knowledge nodes and networks under conditions of contemporary globalization.

\footnotetext{
${ }^{1}$ The terms "post-docs and professors" are used throughout this article to refer to academics and researchers who have received a doctoral degree and/or are working in higher education and/or research and development. As career trajectories and terminologies differ between countries, the terms include mid-level faculty (akademischer Mittelbau), lecturers, readers and full professors.
}

\section{Acknowledgements}

This research was funded by the German Research Council (DFG-Projekt ME 807/18-1). In addition, I gratefully acknowledge the cooperation of the Humboldt Foundation and the project team at the University of Heidelberg, with particular thanks to Peter Meusburger and Verena Jessing. My sincere thanks also go to Alisdair Rogers, Michael Hoyler, Peter Taylor and three anonymous referees for their invaluable suggestions on earlier versions of this article. The views expressed in this article and any errors are solely my responsibility. 


\section{References}

Ackers, L. (2005a) 'Moving people and knowledge: Scientific mobility in the European Union', International Migration, 43 (5), 99-131.

Ackers, L. (2005b) 'Scientific migration within the EU: Introduction to the special issue', Innovation, 18 (3), 275-276.

Adams, J., Gurney, K. and Marshall, S. (2007) Patterns of international collaboration for the UK and leading partners, Leeds: Evidence Ltd.

Altbach, P. G. (1989) 'The new internationalism: foreign students and scholars', Studies in Higher Education, 14 (2), 125-136.

Barnett, R. and Phipps, A. (2005) 'Academic travel: modes and directions', The Review of Education, Pedagogy, and Cultural Studies, 27 (1), 3-16.

Beaverstock, J. V. (2004) "'Managing across borders": knowledge management and expatriation in professional legal service firms', Journal of Economic Geography, 4 (2), 157-179.

Blumenthal, P., Goodwin, C. D., Smith, A. and Teichler, U. (eds) (1996) Academic mobility in a changing world, London: Jessica Kingsley Publishers.

Bourquin, J.-C. (2004) 'National influences on international scientific activity: The case of the French Missions Litteraires in Europe, 1842-1914, in C. Charle, J. Schriewer and P. Wagner (eds) Transnational intellectual networks, Frankfurt: Campus, 451-472.

Carnoy, M. and Castells, M. (2001) 'Globalization, the knowledge society and the network state: Poulantzas at the millennium', Global Networks, 1 (1), $1-18$ 
Castells, M. (2000) The rise of the network society, $2^{\text {nd }}$ edition, Oxford: Blackwell.

Cervantes, M. and Guellec, D. (2002) 'The brain drain: old myths, new realities', OECD Observer, 230, 40-42.

Charle, C. (2004) 'The intellectual networks of two leading universities: Paris and Berlin, 1890-1930', in C. Charle, J. Schriewer and P. Wagner (eds) Transnational intellectual networks, Frankfurt: Campus, 401-450.

Chen, T.-M. and Barnett, G.A. (2000) 'Research on international student flows from a macro perspective: A network analysis of 1985, 1989 and 1995', Higher education, 39 (4), 435-453.

Crang, M. (2003) 'Telling materials', in M. Pryke, G. Rose and S. Whatmore (eds) Using Social Theory: Thinking Through Research, London: Sage, 137-144.

DAAD (ed.) (2007) Wissenschaft weltoffen 2007: Facts and figures on the international nature of studies and research in Germany, Bielefeld: Bertelsmann.

De Certeau, M. (1986) Heterologies: Discourse on the other, Manchester: Manchester University Press.

Enders, J. and Teichler, U. (2005) 'Academics' views of teaching staff mobility: The ERASMUS experience revisited', in A. Welch (ed.) The professoriate: Profile of a profession, Dordrecht: Springer, 97-112.

Faulconbridge, J. R. (2007) 'Relational networks of knowledge production in transnational law firms', Geoforum, 38 (5), 925-940. 
Featherstone, D., Phillips, R. and Waters, J. (2007) 'Introduction: Spatialities of transnational networks', Global Networks, 7 (4), 383-391.

Findlay, A., King, R., Stam A. and Ruiz-Gelices, E. (2006), 'Ever reluctant Europeans: The changing geographies of UK students studying and working abroad', European Urban and Regional Studies, 13 (4), 291-318.

Fulford, T., Lee, D. and Kitson, P. J. (2004) Literature, science and exploration in the romantic era, Cambridge: Cambridge University Press.

Gaillard, A. M. and Gaillard, J. (1997): The international mobility of brains: Exodus or circulation? Science, Technology \& Society, 2 (2), 195-228.

Heffernan, M. J. (1994) 'A state scholarship: The political geography of French international science during the Nineteenth Century', Transactions of the Institute of British Geographers, 19 (1), 21-45.

Heinemann, M. (1994) 'The German universities after the Second World War', in A. Romano and J. Verger (eds) Commission internationale pour I'histoire des universités, III: I poteri politici e il mondo universitario (XIIIXX secolo), Messina: Rubbettino, 257-275.

Hoyler, M. and Jöns, H. (2008) 'Kampf um Talente? Internationalisierung britischer Universitäten durch ausländische Wissenschaftler', Geographische Rundschau, 60 (6), 60-64.

Humboldt Stiftung (ed.) (1999): Grenzenlose Wissenschaft: Deutsche PostDocs im Ausland: 20 Jahre Feodor Lynen-Programm, Bonn: Humboldt Stiftung.

Iredale, R. and Appleyard, R. (2001) 'International migration of the highly skilled: An introduction', International Migration, 39 (5), 3-6. 
Jansen, C. (2004) Exzellenz weltweit: Die Alexander von Humboldt-Stiftung zwischen Wissenschaftsförderung und auswärtiger Kulturpolitik (19532003), unter Mitarbeit von Christoph Nensa, Köln: Dumont.

Jones, A. M. (2008) 'The rise of global work', Transactions of the Institute of British Geographers, 33 (1), 12-26.

Jöns, H. (2003a) Grenzüberschreitende Mobilität und Kooperation in den Wissenschaften, Heidelberg: Department of Geography.

Jöns, H. (2003b) 'Geographies of international scientific exchange in their political context', in J. Nemes Nagy and A. Jakobi (eds) Frontiers of geography, Budapest: Department of Regional Geography, 227-247.

Jöns, H. (2007) 'Transnational mobility and the spaces of knowledge production', Social Geography, 2 (2), 97-114.

Jöns, H. (2008) 'Academic travel from Cambridge University and the formation of centres of knowledge, 1885-1954', Journal of Historical Geography, 34 (2), 338-362.

Kellermann, H. J. (1978) Cultural relations as an instrument of U.S. foreign policy: The educational exchange program between the United States and Germany 1945-1954, Washington: U.S. Department of State.

King, R. (2002) 'Towards a new map of European migration', International Journal of Population Geography, 8 (2), 89-106.

King, R. and Ruiz-Gelices, E., 'International student migration and the European "Year Abroad": Effects on European identity and subsequent migration behaviour', International Journal of Population Geography, 9 (3), 229-252. 
Krauss, M. (2006) '“Gedankenaustausch über Probleme und Methoden der Forschung": Transatlantische Gastprofessoren aus Emigrantenkreisen in Westdeutschland nach 1945‘, Berichte zur Wissenschaftsgeschichte, 29, 243-259.

Latour, B. (1987) Science in action: How to follow scientists and engineers through society, Cambridge, MA: Harvard University Press.

Leydesdorff, L. and Zhou, P. (2005) 'Are the contributions of China and Korea upsetting the world system of science?', Scientometrics 63 (3), 617-630.

Luukkonen, T., Persson, O. and Sivertsen, G. (1992) 'Understanding patterns of international scientific collaboration', Science, Technology, \& Human Values 17 (1), 101-126.

Maiworm, F. and Teichler, U. (2002) 'The academics' views and experiences', in U. Teichler (ed.) ERASMUS in the SOCRATES programme: Findings of an evaluation study, Bonn: Lemmens, 137-159.

Morano-Foadi, S. (2005) 'Scientific mobility, career progression, and excellence in the European Research Area', International Migration, 43 (5), 133-162.

Musselin, C. (2004) 'Towards a European academic labour market? Some lessons drawn from empirical studies on academic mobility', Higher Education, 48 (1), 55-78.

National Science Board (ed.) (1998): Science and engineering indicators 1998, Arlington, VA: National Science Foundation.

Parmar, I. (2002) 'American foundations and the development of international knowledge networks', Global Networks, 2 (1), 13-30. 
Regets, M. C. (2007) 'Research issues in the international migration of highly skilled workers', Working Paper SRS 07-203. Arlington, VA: National Science Foundation.

Robertson, S. L. (2006) 'Brain drain, brain gain and brain circulation', Globalisation, Societies and Education, 4 (1), 1-5.

Saxenian, A. L. (2005) 'From brain drain to brain circulation: Transnational communities and regional upgrading in India and China', Studies in Comparative International Development, 40 (2), 35-61.

Sima, C. M. (2000) 'The role and benefits of the sabbatical leave in faculty development and satisfaction', New Directions for Institutional Research, $105(1), 67-75$.

Smith, M. P. and Favell, A. (eds) (2006) The human face of global mobility: International highly skilled migration in Europe, North America and the Asia-Pacific, New Brunswick, NJ: Transaction Publishers.

Taylor, P. J. (1999) Modernities: A geohistorical interpretation, Cambridge: Polity Press.

Taylor, P. J., Hoyler, M. and Evans, D. M. (2008) 'A geohistorical study of "the rise of modern science": Mapping scientific practice through urban networks, 1500-1900', Minerva, 46 (4), in press.

Teferra, D. (2005) 'Brain circulation: Unparalleled opportunities, underlying challenges, and outmoded presumptions', Journal of Studies International Education, 9 (3), 229-250.

Teichler, U. (1996) 'Research on academic mobility and international cooperation in higher education: An agenda for the future', in P. Blumenthal, C. D. 
Goodwin, A. Smith and U. Teichler (eds) Academic mobility in a changing world, London: Jessica Kingsley Publishers, 338-358.

Universities UK (ed.) (2007) Talent wars: The international market for academic staff, London: Universities UK.

Urry, J. (2000) Sociology beyond societies: Mobilities for the twenty-first century, New York: Routledge.

Van de Sande, D., Ackers, H. L. and Gill, B. (2005) Impact assessment of the Marie Curie Fellowships under the 4th and 5th Framework Programmes of Research and Technological Development of the EU (1994-2002), Brussels: European Commission.

Wagner, C. S. and Leydesdorff, L. (2005a) 'Mapping the network of global science: Comparing international co-authorships from 1990 to 2000', International Journal of Technology and Globalization, 1 (2), 185-208.

Wagner, C. S. and Leydesdorff, L. (2005b) 'Network structure, self-organization, and the growth of international collaboration in science, Research Policy, 34 (10), 1608-1618.

Waters, J. L. (2005) 'Transnational family strategies and education in the contemporary chinese diaspora', Global Networks, 5 (4), 359-377.

Waters, J. L. (2006) 'Emergent geographies of international education and social exclusion', Antipode, 38 (5), 1046-1068.

Waters, J. L. (2007) "Roundabout routes and sanctuary schools": The role of situated educational practices and habitus in the creation of transnational professionals', Global Networks, 7 (4), 477-497. 
Weingart, P. (1998) 'Wissenschaft und Forschung', in B. Schäfers and W. Zapf (eds) Handwörterbuch zur Gesellschaft Deutschlands, Opladen: Leske and Budrich, 720-731.

Welch, A. R. (1997) 'The peripatetic professor: The internationalisation of the academic profession', Higher Education, 34 (3), 323-345.

Woods, R. (1993) 'Classics in human geography revisited: Commentary 1', Progress in Human Geography, 17 (2), 213-15.

Zelinsky, W. (1971) 'The hypothesis of the mobility transition', Geographical Review, 61 (2), 219-249. 


\section{Tables}

Table 1 International co-authors of US scientists and engineers in selected countries (in \%)

\begin{tabular}{lcrc}
\hline Country & $1981-85$ & $1991-95$ & $2001-05$ \\
\hline Canada & 12 & 10 & 11.6 \\
UK & 13 & 10 & 12.9 \\
Germany & 11 & 10 & 13.1 \\
France & 7 & 8 & 8.1 \\
Japan & 7 & 8 & 9.3 \\
China & 2 & 2 & 6.1 \\
\hline
\end{tabular}

Source: National Science Board 1998: Appendix table 5-54; Adams, Gurney, Marshall 2007: 13.

Table 2 Activities of visiting academics in Germany after their research stay (in $\%$ of Humboldt research fellows 1954-2000)

\begin{tabular}{|c|c|c|c|c|c|c|c|c|c|}
\hline & Phys & Chem & Earth & Bio & Med & Math & Eng & Hum & Total \\
\hline \multicolumn{10}{|l|}{ Continued scientific interaction } \\
\hline $\begin{array}{l}\text { Occasional/regular } \\
\text { collaboration }^{\text {ns }}\end{array}$ & 58.0 & 51.4 & 67.4 & 53.3 & 50.8 & 57.2 & 51.0 & 53.6 & 54.1 \\
\hline $\begin{array}{l}\text { Occasional/regular information } \\
\text { exchange }^{\text {ns }}\end{array}$ & 32.9 & 39.0 & 26.7 & 39.6 & 34.2 & 35.1 & 37.8 & 39.1 & 36.9 \\
\hline $\begin{array}{l}\text { Contribution to German-language } \\
\text { journals/book series }\end{array}$ & & & & & & & & & \\
\hline Publishing research results & 10.8 & 25.5 & 46.5 & 23.3 & 42.8 & 27.4 & 29.3 & 71.7 & 39.6 \\
\hline Peer & 5.6 & 9.2 & 19.8 & 10.4 & 12.3 & 24.8 & 13.8 & 29.6 & 17.0 \\
\hline Co-editorsh & 0.4 & 1.2 & 10.5 & 4.2 & 9.6 & 7.7 & 4.8 & 19.2 & 8.6 \\
\hline \multicolumn{10}{|l|}{ Refereeing } \\
\hline lents/researchers from & & & & & & & & & \\
\hline research funding & 22.1 & 16.7 & 37.2 & 25.4 & 20.3 & 34.2 & 26.1 & 34.2 & 26.9 \\
\hline instit & 10.0 & 11.2 & 14.0 & 15.4 & 14.4 & 17.9 & 15.4 & 26.7 & 17.2 \\
\hline \multicolumn{10}{|l|}{ Other academic services } \\
\hline of institutional & 5.2 & 6.4 & 10.5 & 7.5 & 13.4 & 6.8 & 8.5 & 16.4 & 10.3 \\
\hline $\begin{array}{l}\text { Scientific consultin } \\
\text { private and public }\end{array}$ & 5.2 & 6.4 & 4.7 & 3.8 & 10.2 & 3.4 & 12.2 & 3.4 & 5.7 \\
\hline \multicolumn{10}{|l|}{ Permanent job } \\
\hline Professorship $^{\text {ns }}$ & 1.7 & 2.4 & 4.7 & 1.7 & 3.7 & 7.7 & 1.6 & 5.7 & 3.6 \\
\hline Oth & 8.2 & 6.8 & 8.1 & 10.4 & 6.4 & 5.1 & 5.9 & 4.5 & 6.7 \\
\hline Sample size (n) & 231 & 251 & 86 & 240 & 187 & 117 & 188 & 506 & 1,809 \\
\hline
\end{tabular}

Abbreviations: [Phys]ics, [Chem]istry, [Earth] Sciences, [Bio] Sciences, [Med]icine,

[Math]ematics, [Eng]ineering Sciences, Arts and [Hum]anities including the Social Sciences.

Statistically significant differences between disciplines:

ns $=$ not on $1 \%$ level, ${ }^{* * *}=$ on $0.1 \%$ level.

Source: Own postal survey 2003. 
Table 3 Subsequent academic mobility to Germany because of the visiting researchers' contacts (stays of over one month in \% of Humboldt research fellows 1954-2000)

a. By discipline

\begin{tabular}{|c|c|c|c|c|c|c|c|c|c|}
\hline & Phys & Chem & Earth & Bio & Med & Math & Eng & Hum & Total \\
\hline Undergraduates & 3.5 & 6.4 & 8.1 & 8.3 & $\overline{7.0}$ & 4.3 & 11.2 & $\overline{12.8}$ & 8.6 \\
\hline Master students & 6.1 & 4.8 & 5.8 & 5.8 & 6.4 & 3.4 & 14.4 & 9.1 & 7.4 \\
\hline PhD \& other doctoral students ${ }^{\text {ns }}$ & 13.9 & 23.1 & 20.9 & 22.5 & 23.5 & 20.5 & 15.4 & 22.9 & 20.7 \\
\hline Post-Docs ${ }^{\text {ns }}$ & 21.6 & 19.1 & 19.8 & 19.2 & 17.1 & 14.5 & 20.7 & 13.4 & 17.5 \\
\hline Professors ${ }^{\text {ns }}$ & 11.7 & 11.6 & 12.8 & 8.8 & 10.2 & 16.2 & 12.8 & 17.2 & 13.1 \\
\hline Humboldt research fellows" & 51.1 & 42.2 & 48.8 & 45 & 42.2 & 57.3 & 46.3 & 54.0 & 48.8 \\
\hline Sample size (n) & 231 & 251 & 86 & 240 & 187 & 117 & 188 & 506 & 1,809 \\
\hline
\end{tabular}

Abbreviations: [Phys]ics, [Chem]istry, [Earth] Sciences, [Bio] Sciences, [Med]icine,

[Math]ematics, [Eng]ineering Sciences, Arts and [Hum]anities including the Social Sciences.

Statistically significant differences between disciplines:

ns $=$ not on $1 \%$ level, ${ }^{* *}=$ on $1 \%$ level, ${ }^{* * *}=$ on $0.1 \%$ level.

Source: Own postal survey 2003.

b. By selected regions and countries of origin

\begin{tabular}{|c|c|c|c|c|c|c|c|c|c|c|}
\hline & USA & CSA & EU15 & $\overline{E C E}$ & RUS & AFR & IND & $\mathrm{CHN}$ & JAP & AUS \\
\hline Undergraduates $^{\text {ns }}$ & $\overline{7.1}$ & $\overline{11.8}$ & $\overline{12.0}$ & 8.0 & $\overline{5.3}$ & 8.1 & 8.5 & 9.2 & $\overline{4.0}$ & $\overline{7.3}$ \\
\hline Master students $^{\text {ns }}$ & 4.4 & 15.1 & 8.1 & 7.2 & 3.2 & 3.5 & 7.0 & 8.0 & 5.1 & 7.3 \\
\hline PhD \& other doctoral students & 7.1 & 36.6 & 21.6 & 22.0 & 23.4 & 30.2 & 24.8 & 12.6 & 14.1 & 20.0 \\
\hline Post-Docs & 6.6 & 12.9 & 16.6 & 26.1 & 22.3 & 18.6 & 21.7 & 23.0 & 13.6 & 23.6 \\
\hline Professors & 12.6 & 17.2 & 11.3 & 7.2 & 10.6 & 17.4 & 14.7 & 17.2 & 23.7 & 12.7 \\
\hline Humboldt research fellows & 36.3 & 41.9 & 45.2 & 60.2 & 61.7 & 46.5 & 49.6 & 35.6 & 41.2 & 43.6 \\
\hline Sample size (n) & 182 & 93 & 283 & 264 & 94 & 86 & 129 & 87 & 177 & 55 \\
\hline
\end{tabular}

Abbreviations: [USA], [C]entral and [S]outh [A]merica including Mexico; [E]uropean [U]nion of [15] countries, [E]ast [C]entral [E]urope; [RUS]sian Federation, [AFR]ica, [IND]ia, [CH]i[N]a, [JAP]an, [AUS]tralia.

Statistically significant differences between regions:

ns $=$ not on $1 \%$ level, ${ }^{* * *}=$ on $0.1 \%$ level.

Source: Own postal survey 2003. 
Table 4 Geographies of international collaboration in the natural and technical sciences

\begin{tabular}{|c|c|c|c|c|c|}
\hline Country of origin & Rank & $\begin{array}{r}\text { Internatio } \\
15\end{array}$ & rship, & $\begin{array}{l}\text { Most import } \\
\text { collaboratio } \\
\text { research fellov }\end{array}$ & $\begin{array}{l}\text { onal } \\
\text { oldt } \\
00(\%)\end{array}$ \\
\hline$\overline{U S A}$ & 1 & Canada & 10 & Germany & 41 \\
\hline & 2 & UK & 10 & UK & 9 \\
\hline & 3 & Germany & 10 & France & 5 \\
\hline China & 1 & USA & 28 & Germany & 38 \\
\hline & 2 & Japan & 11 & USA & 19 \\
\hline & 3 & Germany & 5 & Japan & 7 \\
\hline Japan & 1 & USA & 40 & Germany & 42 \\
\hline & 2 & UK & 7 & USA & 18 \\
\hline & 3 & Germany & 7 & UK & 7 \\
\hline Poland & 1 & USA & 17 & Germany & 31 \\
\hline & 2 & Germany & 16 & USA & 16 \\
\hline & 3 & France & 9 & France & 11 \\
\hline Russian & 1 & USA & 16 & Germany & 32 \\
\hline Federation & 2 & Germany & 15 & USA & 15 \\
\hline & 3 & France & 8 & France & 10 \\
\hline India & 1 & USA & 28 & Germany & 38 \\
\hline & 2 & UK & 10 & USA & 25 \\
\hline & 3 & Germany & 10 & UK & 10 \\
\hline France & 1 & USA & 20 & Germany & 30 \\
\hline & 2 & Germany & 10 & USA & 11 \\
\hline & 3 & UK & 8 & UK/France & 11 \\
\hline Italy & 1 & USA & 22 & Germany & 36 \\
\hline & 2 & UK & 10 & USA & 30 \\
\hline & 3 & France & 10 & France/Spain & 8 \\
\hline Hungary & 1 & USA & 22 & Germany & 28 \\
\hline & 2 & Germany & 16 & USA & 13 \\
\hline & 3 & UK/France & 7 & France/Austria & 8 \\
\hline Great Britain & 1 & USA & 23 & Germany & 33 \\
\hline & 2 & Germany & 8 & USA & 23 \\
\hline & 3 & France & 7 & France & 17 \\
\hline Australia & 1 & USA & 29 & Germany & 38 \\
\hline & 2 & UK & 16 & USA & 20 \\
\hline & 3 & Germany & 7 & UK & 15 \\
\hline Spain & 1 & USA & 18 & Germany & 31 \\
\hline & 2 & France & 15 & USA & 15 \\
\hline & 3 & UK & 12 & France & 8 \\
\hline
\end{tabular}

Source: National Science Board 1998: Appendix table 5-54; own postal survey 2003. 


\section{Figures}

Figure 1 Geographies of academic mobility to Germany, 1954-2000

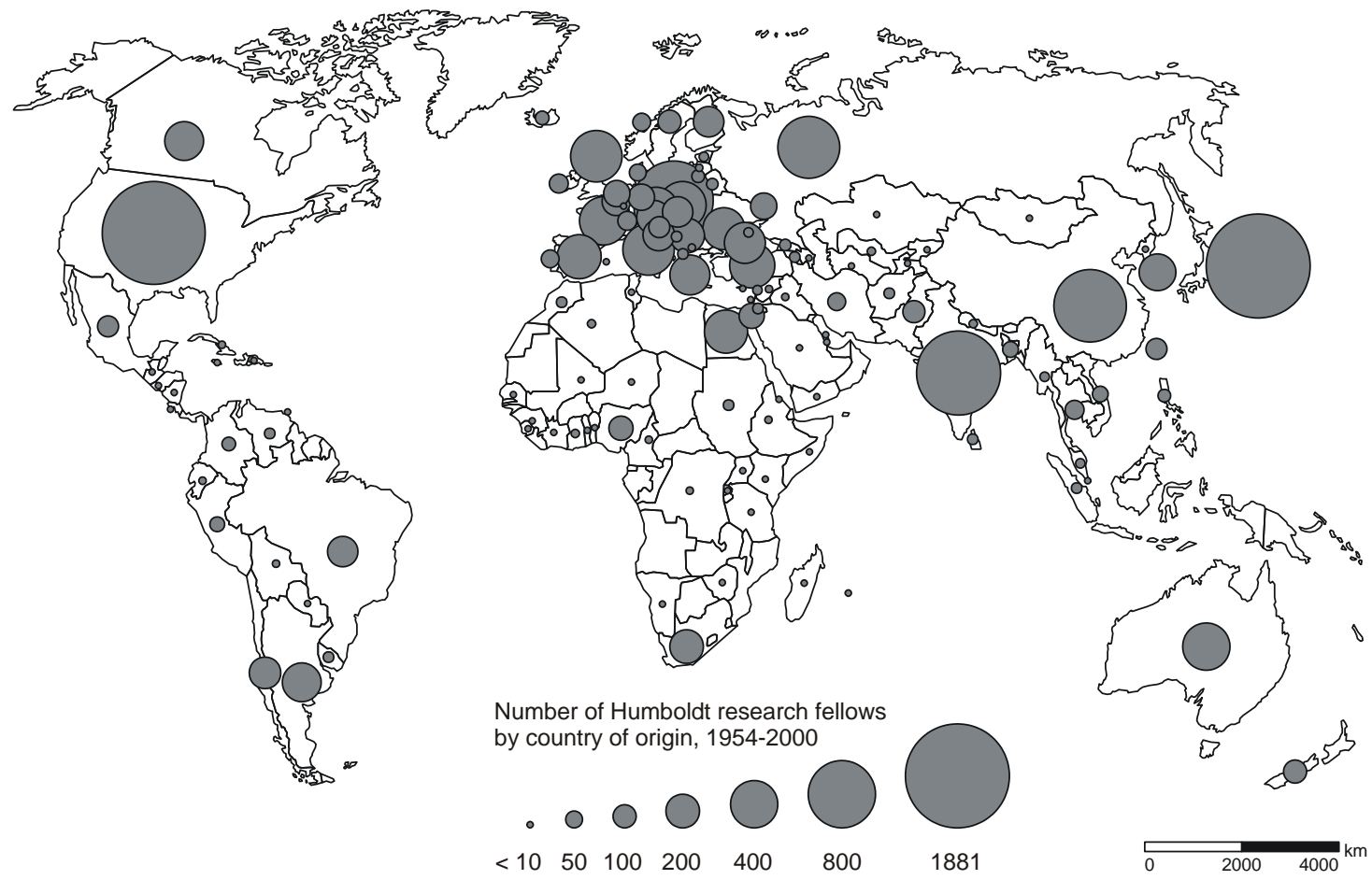

Source: Database of the Humboldt Foundation. 
Figure 2 Applications for Humboldt research fellowships, 1954-2000

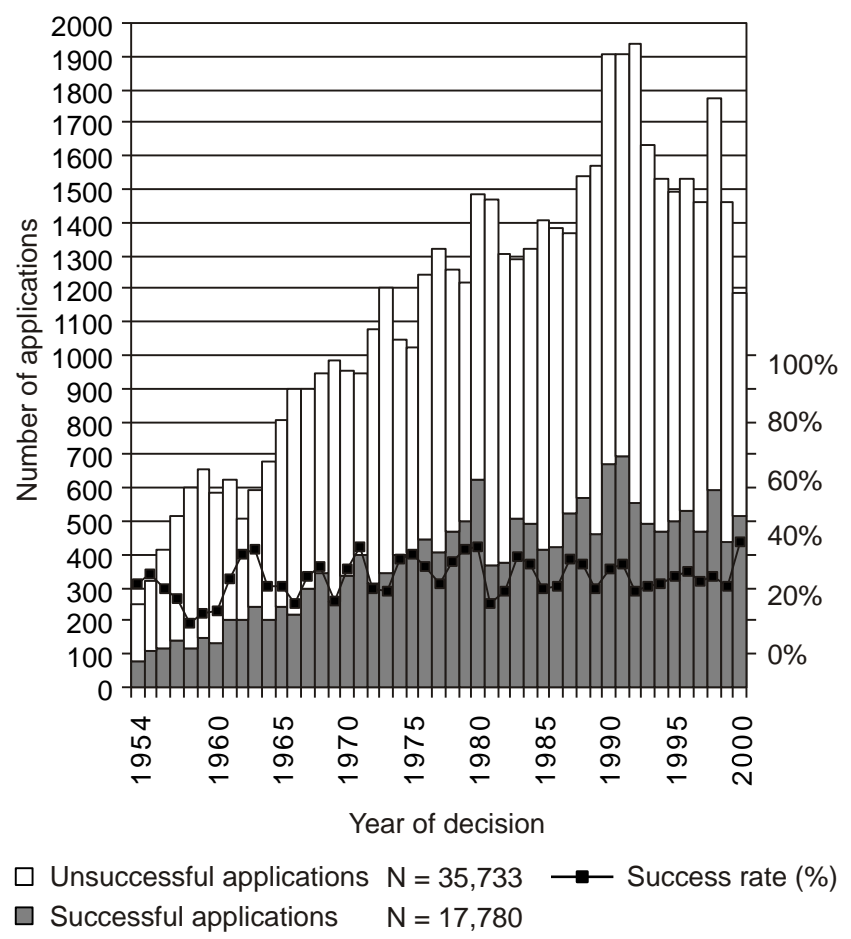

Source: Database of the Humboldt Foundation.

Figure 3 The changing profile of Humboldt research fellows, 1954-2000

a. By region of country of origin

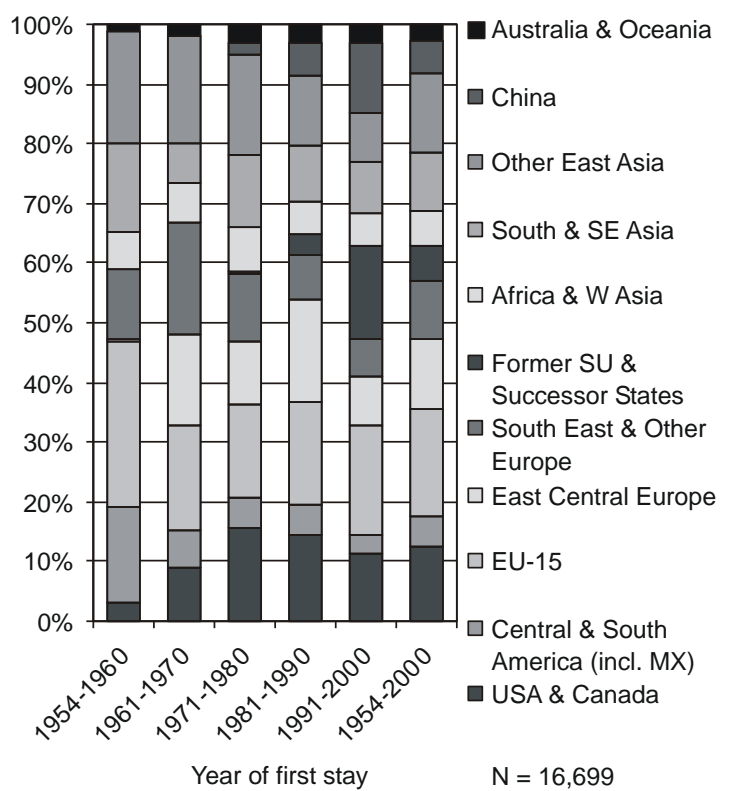

b. By discipline

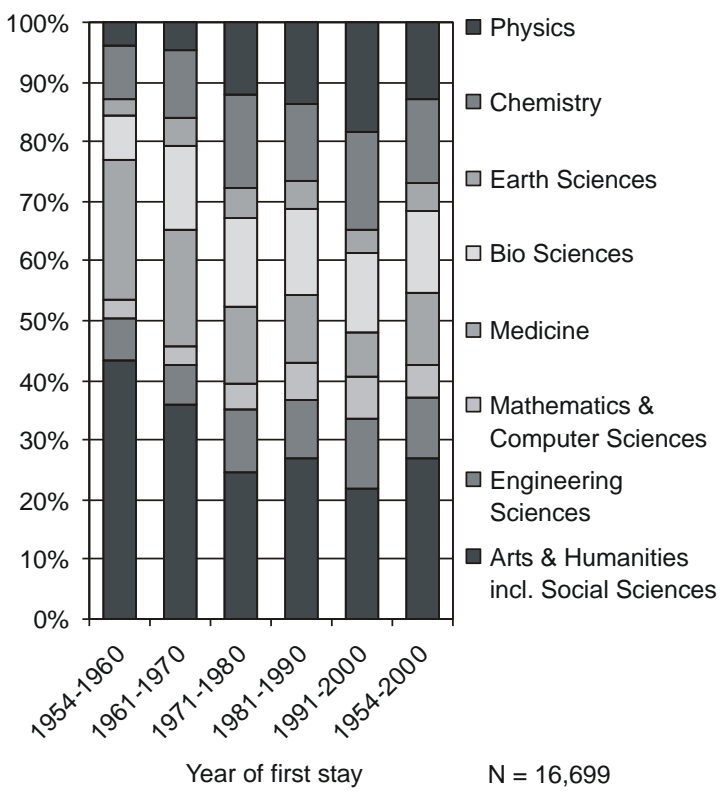

Source: Database of the Humboldt Foundation. 
Figure 4 Subsequent academic mobility because of the visiting researchers' contacts (in \% of Humboldt research fellows 1954-2000)

a. From Germany to abroad

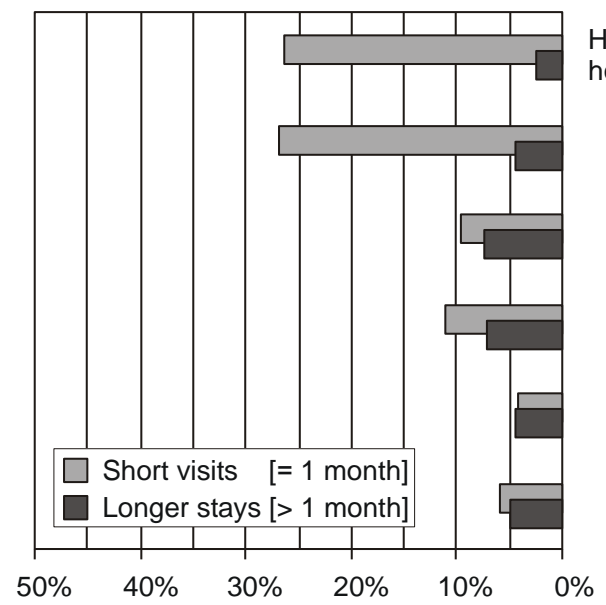

b. From abroad to Germany

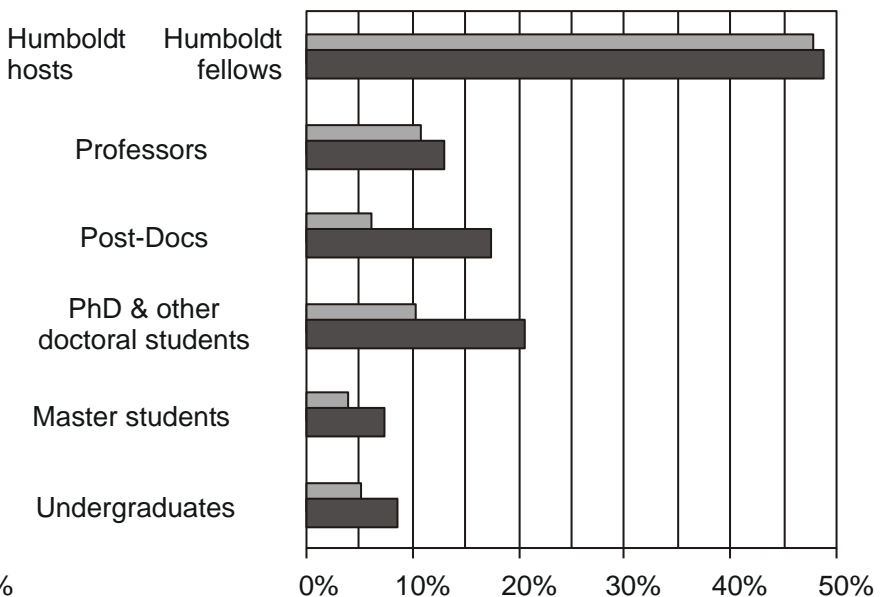

Source: Own postal survey 2003. 